Supporting Information

\title{
Odd-Even Effect of the Methylene Chain Number in the Template Polymerization of $\alpha, \beta$-Diacetylenecarboxylates Incorporated in Layered Double Hydroxide Clay
}

\author{
Toshio Itoh, Tetsuya Shichi, Tatsuto Yui, and Katsuhiko Takagi*
}

\section{(P. 4, 1. 15-18)}

Synthesis of Diacetylenecarboxylic Acid. mono-[10,4]: $\quad{ }^{1} \mathrm{H}-\mathrm{NMR}$ (vs TMS): $\delta 0.88(\mathrm{t}, J=7.0 \mathrm{~Hz}$, $3 \mathrm{H}), 1.22-1.34(\mathrm{~m}, 12 \mathrm{H}), 1.34-1.42(\mathrm{~m}, 2 \mathrm{H}), 1.52(\mathrm{~m}, J=7.0 \mathrm{~Hz}, 2 \mathrm{H}), 1.86(\mathrm{~m}, J=7.0 \mathrm{~Hz}, 2 \mathrm{H}), 2.24(\mathrm{t}$, $J=7.0 \mathrm{~Hz}, 2 \mathrm{H}), 2.36(\mathrm{t}, J=7.0 \mathrm{~Hz}, 2 \mathrm{H})$, and 2.51(t, $J=7.5 \mathrm{~Hz}, 2 \mathrm{H})$. mono-[10,5]: ${ }^{1} \mathrm{H}-\mathrm{NMR}$ (Me ester derivative, vs TMS): $\delta 0.88(\mathrm{t}, J=7.0 \mathrm{~Hz}, 3 \mathrm{H}), 1.22-1.42(\mathrm{~m}, 14 \mathrm{H}), 1.48-1.60(\mathrm{~m}, 4 \mathrm{H}), 1.74(\mathrm{~m}$, $J=7.5 \mathrm{~Hz}, 2 \mathrm{H}), 2.24(\mathrm{t}, J=7.0 \mathrm{~Hz}, 2 \mathrm{H}), 2.28(\mathrm{t}, J=7.0 \mathrm{~Hz}, 2 \mathrm{H}), 2.33(\mathrm{t}, J=7.5 \mathrm{~Hz}, 2 \mathrm{H})$, and $3.67(\mathrm{~s}, 3 \mathrm{H})$.

mono-[13,4]: ${ }^{1} \mathrm{H}-\mathrm{NMR}$ (vs TMS): $\delta 0.88(\mathrm{t}, J=7.0 \mathrm{~Hz}, 3 \mathrm{H}), 1.22-1.34(\mathrm{~m}, 18 \mathrm{H}), 1.34-1.42(\mathrm{~m}, 2 \mathrm{H})$, $1.52(\mathrm{~m}, J=7.0 \mathrm{~Hz}, 2 \mathrm{H}), 1.86(\mathrm{~m}, J=7.0 \mathrm{~Hz}, 2 \mathrm{H}), 2.24(\mathrm{t}, J=7.0 \mathrm{~Hz}, 2 \mathrm{H}), 2.36(\mathrm{t}, J=7.0 \mathrm{~Hz}, 2 \mathrm{H})$, and 2.51(t, $J=7.5 \mathrm{~Hz}, 2 \mathrm{H})$. mono-[13,5]: ${ }^{1} \mathrm{H}-\mathrm{NMR}$ (Me ester derivative, vs TMS): $\delta 0.89(\mathrm{t}, J=7.0 \mathrm{~Hz}$, $3 \mathrm{H}), 1.22-1.34(\mathrm{~m}, 20 \mathrm{H}), 1.34-1.44(\mathrm{~m}, 2 \mathrm{H}), 1.52(\mathrm{~m}, J=7.5 \mathrm{~Hz}, 2 \mathrm{H}), 1.75(\mathrm{~m}, J=7.5 \mathrm{~Hz}, 2 \mathrm{H}), 2.25(\mathrm{t}$, $J=7.0 \mathrm{~Hz}, 2 \mathrm{H}), 2.29(\mathrm{t}, J=7.0 \mathrm{~Hz}, 2 \mathrm{H}), 2.34(\mathrm{t}, J=7.5 \mathrm{~Hz}, 2 \mathrm{H})$, and $3.69(\mathrm{~s}, 3 \mathrm{H})$.

The Polymerization of Non-Intercalated poly-[m,n]. The non-intercalated mono-[m,n] powders were placed in a pyrex vessel under Ar atmosphere and irradiated with $\gamma$-rays from ${ }^{60} \mathrm{Co}$ at $1.12 \times 10^{4}$ Gy in room temperature to form the poly(diacetylenecarboxylates) or poly-[m,n].

(p. 5, 1. 10-p. 6 1. 3)

X-ray Diffraction Analysis of Non-Intercalated poly-[m,n]. The XRD patterns were measured at a scan rate of $1 \mathrm{deg} / \mathrm{min}$. The lamellar distance was calculated by the averaged $d$ value of the peaks assigned to the bilayer poly-[m,n] within the poly-[m,n]/LDH. The XRD patterns of these poly-[m,n] powders indicated that an increase in the lamellar distance depended on an increase in 
the methylene chain length, as shown in Figure S1. Moreover, the effect of the odd or even numbered $\mathbf{n}$ could not be observed in the XRD patterns.

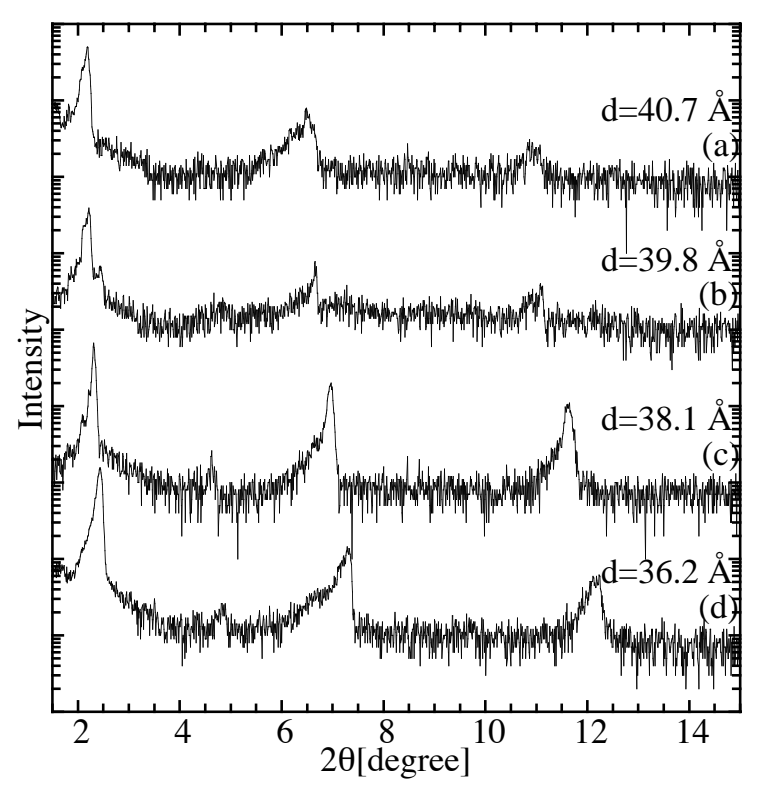

Figure S1. XRD patterns of non-intercalated poly-[m,n]: (a) poly-[13,5]; (b) poly-[13,4]; (c) poly-[10,5]; and (d) poly-[10,4].

(p. 7, 1. 11-29)

Polymerization Degree $\left(\mathrm{N}_{\mathrm{D}}\right)$ of the Non-Intercalated poly-[m,n] by Gel Permeation Chromatography. Each poly-[m,n] powder was treated with $3 \mathrm{~mol} \cdot \mathrm{dm}^{-3} \mathrm{HCl}$, extracted with chloroform, methylated with diazomethane, evaporated, and again dissolved in dried chloroform, filtrated with a disposable filter unit (Advantec Dismic PTFE $0.20 \mu \mathrm{m}$ ), and finally analyzed. The non-intercalated poly-[m,n] powders exhibited no "odd or even numbered effect of $\mathbf{n}$ ", as shown in Figure S2. Moreover, it was noted that the polymerization degree $\mathrm{N}_{\mathrm{D}}$ of the non-intercalated poly[m,n] powders shown in Figure S2 do not include components which cannot be extracted by $\mathrm{CHCl}_{3}$ due to the insolubility of the higher polymeric components in chloroform. 


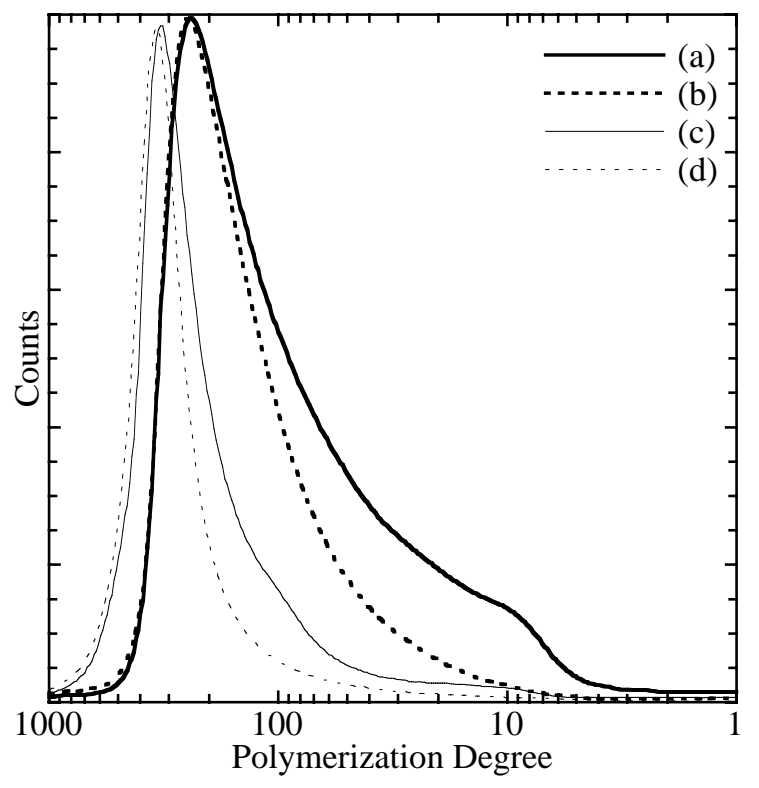

Figure S2. GPC chart of the non-intercalated poly-[m,n]: (a) poly-[13,5]; (b) poly-[13,4]; (c) poly-[10,5]; and (d) poly-[10,4]. 